\title{
Sinonasal desmoplastic small round cell tumor: a case report and review of the literature
}

\author{
Yanli Tao ${ }^{1,2+}$, Lina Shi ${ }^{3+}$, Li Ge ${ }^{4}$, Tiejun Yuan² and Li Shi ${ }^{1 *}$
}

\begin{abstract}
Background: Desmoplastic small round cell tumor (DSRCT) is a rare malignancy with poor prognosis that generally involves the peritoneum. Its diagnosis can be achieved only by immunohistochemistry and cytogenetic studies.

Case presentation: In the current report, a 55-year-old female was admitted in our hospital for evaluation of right eye epiphora and right nasal intermittent bleeding. Imaging examination revealed a large soft tissue mass in the right nasal cavity and ethmoid sinus. After an explorative surgery, the pathological findings confirmed the presentation of sinonasal DSRCT. Immunohistochemistry and cytogenetic studies confirmed the diagnosis of DSRCT in this patient. Surgical resection, chemotherapy, and radiotherapy was performed, and she died 2 months after operation.

Conclusion: This reported case draws attention to the importance of novel treatments and including DSRCT in the differential diagnosis of sinonasal tumors.
\end{abstract}

Keywords: Desmoplastic small round cell tumor, Surgical resection, Multimodal management

\section{Background}

Desmoplastic small round cell tumor (DSRCT) is a rare and aggressive mesenchymal malignancy. Only 850 such patients were reported in the medical literature [1]. First described in 1989 [2, 3], DSRCT's name derives from its distinctive histological findings, which include clusters of undifferentiated, small round blue cells surrounded by abundant desmoplasia.

Patients with DSRCT are usually between 5 and 30 years of age. Males and older adolescents are more often affected $[4,5]$. The most commonly affected region is the pelvis, other sites mainly include the omentum, the spatium retroperitoneale and the mesentery [6-8]. Tumors located in the abdomen or pelvis generally require a period of growth before they can cause symptoms of the body. When the symptoms of the body appear, it is usually atypical, mainly characterized by abdominal pain, weight loss, abdominal

\footnotetext{
*Correspondence: shili_medical@126.com

†Yanli Tao and Lina Shi contributed equally to this article thus shared the cofirst authors.

'Department of Otolaryngology, The Second Hospital of Shandong

University, 247\#, Beiyuan Street, Jinan 250033, China

Full list of author information is available at the end of the article
}

fullness, etc. Therefore, DSRCT is often diagnosed when the tumor has metastasized or is in the advanced stage of the disease. According to the SEER database, only about onefifth of patients are diagnosed with only localized disease [4].

In spite of great advances in medical technology, the treatment of DSRCT remains a challenge for doctors. There are currently no standardized treatment approaches. Surgical resection combined with chemotherapy and radiotherapy are the main treatment methods at present [5]. Surgery is currently the best treatment option. The 3-year survival rate for complete tumor resection cases was reported to be $58 \%$, compared to $0 \%$ in unresectable cases [9]. However, surgery does not produce any benefit for patients with extraperitoneal metastases [10]. DSRCT still has a poor prognosis despite these multimodal treatments, with a 3-year survival rate of less than $30 \%$ and a 5-year survival rate of only $18 \%[11,12]$. Therefore, novel therapy is required.

We present a recent case of sinonasal DSRCT and review the literature. The purpose of this study is to describe the microscopic patterns and cytological criteria as well as to describe our experience in the diagnosis and treatment of DSRCT. 


\section{Case presentation}

A 55-year-old female was admitted in our hospital for right eye epiphora and right nasal intermittent bleeding on August 2018. Nasal endoscopy revealed a right nasal mass located in the middle nasal meatus. A magnetic resonance imaging (MRI) and computed tomography (CT) scans showed a large soft tissue masse in the right nasal cavity and ethmoid sinus, which invaded the right lamina papyracea, the right frontal sinus and the right side of nasal septum. The medial wall of the right superior collar sinus, middle turbinate and part of ethmoid sinus septum were accompanied by erosive bone resorption (Fig. 1a-b). Swollen lymph nodes can be seen in the right neck. The patient underwent endoscopic biopsy of the right ethmoid sinus and pathological examination. Fragments of soft to firm gray and tan tissue were submitted for pathologic examination. The sinus tumors in the right nasal cavity were resected under nasal endoscope.

Diagnosis required confirmation of histopathological features, polyphenotypic immunohistochemical reactivity, and molecular/cytogenetic findings [13], therefore the following experiments were performed.

\section{Histopathological manifestations}

Under the light microscope, the lesions were composed of irregular lamellae and nested tumor cells and the surrounding fibrous interstitial cells. The tumor cells in the nest are small round or oval, with few cytoplasm, unclear cell boundaries, round or oval hyperchromatic nuclei, unclear nucleoli, and mitotic figures were easy to observe (Fig. 2a-b). The stroma is a proliferative dense fibrous connective tissue composed of fibroblasts and myofibroblasts with mucoid degeneration. In this case, the tumors invaded bone.

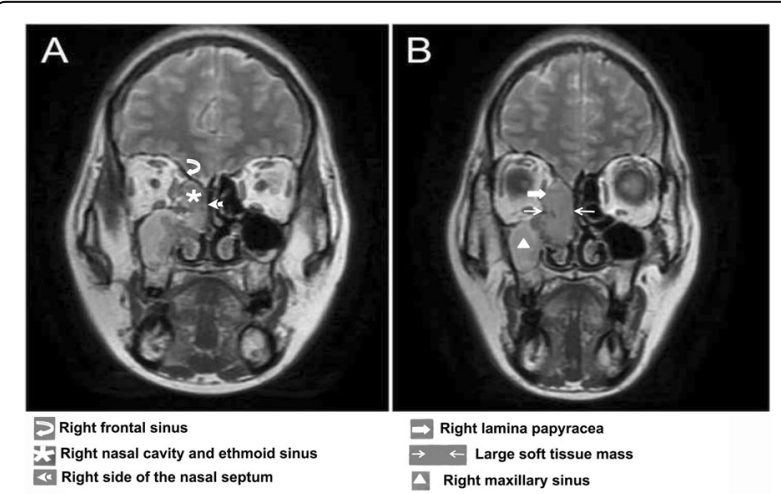

Fig. 1 Imaging changes of the patient before surgery. Large soft tissue mass located in the right nasal cavity and ethmoid sinus, invading the right lamina papyracea, right frontal sinus, right side of the nasal septum. The medial wall of right maxillary sinus, the ethmoid cornua, and part of the ethmoid sinus were observed with erosional bone resorption and destruction

\section{Immunohistochemical staining}

Immunohistochemistry gave the following phenotypic markers: CD56 (+) (Fig. 2c), Vimentin (+), WT-1 (+) (Fig. 2d), S-100(-), Desmin (-), CD99 (-), with a Ki-67 index of 95\% (Fig. 2e). Vim showed characteristic dotlike perinuclear staining pattern (Fig. 2f), and did not express EMA, Desmine, S-100, MyoDl, CD20, CD3, CD7 and P63.

\section{Bone marrow puncture results}

Blood smear: There is no obvious increase or decrease of white blood cells, neutrophils are almost normal, and middle and late red blood cells account for 6/100 nucleated cells, and platelets are scattered. (Fig. 2g).

Bone marrow smear: Bone marrow proliferation was active, $\mathrm{G}=49.0 \%, \mathrm{E}=21.0 \%, \mathrm{G} / \mathrm{E}=2.33: 1$. The main stage of granulocytes was below the middle and young granulocytes, with no obvious morphological abnormalities. All stages of the erythroid system were noticed, there was no obvious abnormality in morphology, and the size of mature red blood cells was uneven. The cancer cells were scattered or clustered. Their cell bodies were large, the boundaries were unclear, round or irregular, with a large amount of cytoplasm, stained with purple-blue or purple-red, partially foamy, with large nuclei and chromatin accumulation. Naked nuclear tumor cells were frequently observed. Plasmacytes and histiocytes were easy to observe. No megakaryocytes and thrombocytopenia were found in the whole smear. (Fig. 2h).

\section{Treatment and outcome}

During the operation, a small part of the tumors were removed by forceps and sent for rapid frozen pathological diagnosis. The results showed that the tumors were small cell malignant tumors. After the uncinate process was removed, the maxillary sinus was opened and the purulent secretions in the maxillary sinus were sucked out. The maxillary sinus orifice and the medial wall of the maxillary sinus were removed and sent to pathology. The pathological results showed that the orbital cardboard was partially absorbed. Then the orbital cardboard and the orbital fascia were fully separated and removed. After resection of the right frontal sinus mass, the right middle turbinate was removed. It was found that the nasal cavity mass was grey-white fish-like and invaded the right frontal sinus, the right orbital cardboard and the medial wall of the right maxillary sinus. The orbital fascia was intact. Postoperative pathology showed that the tumors were found in the right orbital wall, the right maxillary sinus wall, the posterior wall, the posterior inferior wall and the right middle turbinate root. Chemotherapy and radiotherapy was performed, but the patient was found to have bone marrow metastasis and presented with persistent nasal bleeding and she died 2 months after operation. 


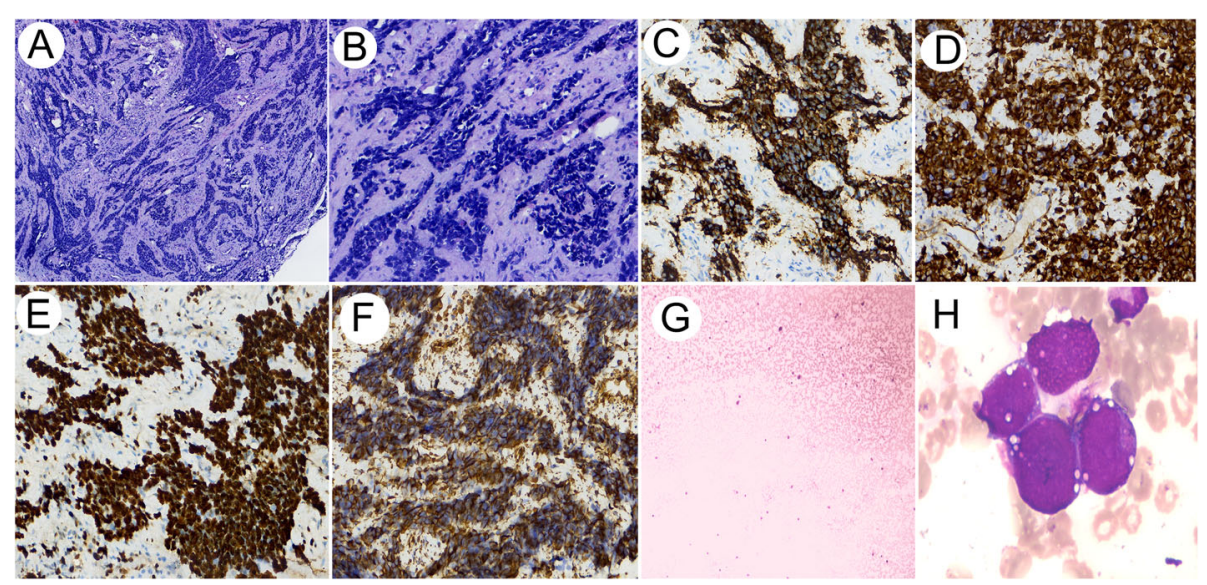

Fig. 2 a-b HE morphology of the patient. Tumor cells were irregular sheet-like and nest-like distribution, surrounded by proliferative fibrous stroma. The tumor cells in the nest are small round or oval, with few cytoplasm, unclear cell boundaries, round or oval hyperchromatic nuclei, unclear nucleoli, and mitotic figures were easy to observe (10x and 40x). c-d Desmoplastic small round cell tumor shows immunoreactivity for CD56 (40x) and WT-1 (40x). e Desmoplastic small round cell tumor shows positive Ki-67 with an index of 95\% (40x). $\mathbf{f}$ Vim stain revealed the characteristic dot-like perinuclear pattern (40x). g Blood smear showed no obvious increase or decrease of white blood cells, normal neutrophils, and middle and late red blood cells account for 6/100 nucleated cells, and platelets were scattered. $\mathbf{h}$ Bone marrow smear image. The cancer cells were scattered or clustered. Their cell bodies were large with unclear boundaries and a large amount of cytoplasm, stained with purple-blue or purple-red, partially foamy, with large nuclei and chromatin accumulation. Naked nuclear tumor cells were frequently observed

\section{Discussion and conclusion}

DSRCT usually occurs between 5 and 50 years with an average age of 22 years. In general, nearly $85-90 \%$ of patients are male, but in patients younger than 20 years old at the time of diagnosis, the proportion of females is slightly higher [9]. The clinical manifestations of DSRCT are not typical, and patients often experience abdominal or pelvic discomfort, typically including abdominal pain and/or bloating, ascites, constipation, and urinary tract disease [14-16].

DSRCT, which occurs in the nasal cavity and sinuses, is extremely rare, and only two cases reported in the literature were retrieved on PubMed, their clinical features, treatment and outcomes were summarized in Table 1. Its clinical manifestations are complex and varied. Generally, local symptoms occur according to different parts of the body, without its own unique clinical manifestations. If it occurs in the abdominal cavity or pelvic cavity, clinical manifestations are usually abdominal pain, abdominal distension or abdominal mass, which can be accompanied by cachexia such as fever, anemia, emaciation, and prone to substantial organs and lymph node metastasis; while in the nasal cavity and paranasal sinuses, the primary symptoms are mainly sinusitis, nosebleeds and nasal congestion, local infiltration and cervical lymph node metastasis may occur, and small round cell malignant swelling is common in this area. The clinical manifestations of the tumors were not significantly different, and it was difficult to make a definite diagnosis in clinic.

Despite multimodal therapy, patients with DSRCT overall have very poor survival rates of $15-30 \%$ at 5 years $[4,5]$. The case in this report died 2 months after surgery because of bone marrow metastasis of the tumor, which may be one of the reasons for the poor prognosis in the current case compared with the cases reported in the literature.

The majority of desmoplastic small round cell tumors can be reliably diagnosed based on the characteristic morphology and immunohistochemical profile. Most literatures reported that DSRCT cells expressed epithelial, mesenchymal and neuroendocrine markers [19]. However, some reports showed that the immunophenotype of some

Table 1 Case reports of sinonasal desmoplastic small round cell tumors reported in the literature

\begin{tabular}{|c|c|c|c|c|c|}
\hline Author & $\begin{array}{l}\text { Age }(y), \\
\text { Gender }\end{array}$ & Main symptom & Tumor location & Treatment & $\begin{array}{l}\text { Patient outcome at } \\
\text { time of report }\end{array}$ \\
\hline $\begin{array}{l}\text { Present } \\
\text { study }\end{array}$ & $55, F$ & $\begin{array}{l}\text { Right eye epiphora, right nasal } \\
\text { intermittent bleeding }\end{array}$ & $\begin{array}{l}\text { Right ethmoidal sinus, frontal sinus } \\
\text { and lamina papyracea }\end{array}$ & Tumor resection & Survival of 12 mo \\
\hline $\begin{array}{l}\text { Fink MD. et } \\
\text { al. [17] }\end{array}$ & $21, F$ & Chronic sinusitis & $\begin{array}{l}\text { Frontal, ethmoidal and sphenoid } \\
\text { sinus }\end{array}$ & $\begin{array}{l}\text { Tumor resection; } \\
\text { Radiotherapy; Chemotherapy }\end{array}$ & $\begin{array}{l}\text { Survival of more } \\
\text { than } 26 \mathrm{mo}\end{array}$ \\
\hline $\begin{array}{l}\text { LOPEZ F. et } \\
\text { al. [18] }\end{array}$ & $61, M$ & $\begin{array}{l}\text { Stuffy and bleeding of right-side } \\
\text { nose occasionally }\end{array}$ & $\begin{array}{l}\text { Right ethmoidal sinus and anterior } \\
\text { cranial fossa }\end{array}$ & $\begin{array}{l}\text { Tumor resection; } \\
\text { Radiotherapy }\end{array}$ & $\begin{array}{l}\text { Survival of more } \\
\text { than } 29 \text { mo }\end{array}$ \\
\hline
\end{tabular}

$F$ Female, $M$ Male 
DSRCTs were atypical, only expressed Vim, CD56 and other markers, but did not express epithelial and neurogenic or myogenic markers [20]. Des and NSE were not expressed in this case, but only Vim, CD56 and WT-1 markers, which made it difficult to diagnose and differential diagnose. Therefore, familiarity with the characteristic immunophenotypes and molecular pathological changes of DSRCT will be helpful in differential diagnosis.

Due to its histological similarities with other malignant 'small' round cell tumors, DSRCT has been confused histologically with other lesions, including primary olfactory neuroblastoma [21], small-cell anaplastic carcinoma and Ewing sarcoma /primitive neurotodermal tumor (PENT). Olfactory neuroblastoma usually occurs in olfactory cleft. Comparison between DSRCT and other small round cell tumors were shown in Table 2. Neurogenic markers such as NSE and synaptic vesicle protein were strongly positive in tumor cells, while low molecular weight keratin was weakly expressed in only a few cases. Myogenic and epithelial antigens were not expressed and S100 was expressed in sertoli cells around the tumor nest. These clinical and pathological features as well as molecular pathological examination are helpful in differentiating DSRCT. Secondly, it is necessary to identify small-cell anaplastic carcinoma. The tumor cells express epithelial markers, partially express neuroendocrine markers, but lack obvious multidirectional differentiation, do not express myogenic markers, and have few interstitial. The dot-like expression of Vim in DSRCT tumor cells is of great value in differential diagnosis [22]. The third is extraosseous Ewing sarcoma /primitive neurotodermal tumor (PENT), which is predominantly located in the lower extremities, spine, retroperitoneum and pleura. It can also occur in the nasal cavity and paranasal sinuses. Its onset age, histological morphology, immunophenotype and molecular pathological changes overlap with DSRCT to a certain extent. When Ewing sarcoma /PENT tumors contain a large amount of fibrous connective tissue, it is very easy to be misdiagnosed as DSRCT [23]. However, the former generally does not express epithelial or myogenic markers, CD99 is strongly

Table 2 Comparison between DSRCT and other small round cell tumors

\begin{tabular}{|c|c|c|c|c|}
\hline Item & DSRCT & $\begin{array}{l}\text { Extraosseous Ewing's } \\
\text { sarcoma/primitive } \\
\text { neuroectodermal tumors } \\
\text { (PNET) }\end{array}$ & Olfactory neuroblastoma & $\begin{array}{l}\text { Small cell undifferentiated } \\
\text { carcinoma }\end{array}$ \\
\hline $\begin{array}{l}\text { Morphological } \\
\text { characteristics }\end{array}$ & $\begin{array}{l}\text { Nests of small round cells } \\
\text { vary in size and shape, and } \\
\text { there are a large number of } \\
\text { fibrous connective tissue } \\
\text { stroma between the nests of } \\
\text { tumor cells. Tumor cells are } \\
\text { closely arranged, thin and } \\
\text { sparse, with unclear cell } \\
\text { boundaries, round or oval } \\
\text { nuclei, hyperchromatic nuclei, } \\
\text { unclear nucleoli, and mitotic } \\
\text { figures are easy to see }\end{array}$ & $\begin{array}{l}\text { Round cells are compactly } \\
\text { patchy/lobular, and } \\
\text { fibrovascular septa are } \\
\text { observed between lobules } \\
\text { with varying width of fibrous } \\
\text { connective tissue. The } \\
\text { cytoplasm of the tumor cells } \\
\text { is scarce and unclear, but } \\
\text { some of the cytoplasmic } \\
\text { margins could be bright or } \\
\text { vacuolar. The nuclei are } \\
\text { round/oval, dark-stained/ } \\
\text { uniform pepper-salt-like, and } \\
\text { the mitotic figures vary. }\end{array}$ & $\begin{array}{l}\text { Round cells are nested/ } \\
\text { lobulated, and interlobular } \\
\text { spaces are vascular-rich } \\
\text { fibrous connective tissue. } \\
\text { Tumor cells differentiate in } \\
\text { different degrees. The well- } \\
\text { differentiated nuclei of tumor } \\
\text { cells have no obvious atypia, } \\
\text { fine chromatin, no obvious } \\
\text { nucleoli, few mitotic images } \\
\text { and more nerve fiber } \\
\text { networks in the interstitium. } \\
\text { The poorly differentiated } \\
\text { tumors have obvious nuclear } \\
\text { atypia, easily seen mitotic } \\
\text { images, few/absent interstitial } \\
\text { fibrous networks and a large } \\
\text { number of necrosis. }\end{array}$ & $\begin{array}{l}\text { Small round cells without } \\
\text { specific morphology }\end{array}$ \\
\hline Immunohistochemistry & $\begin{array}{l}\text { Multidirectional differentiation } \\
\text { and positive expression: } \\
\text { epithelial marker, } \\
\text { neuroendocrine marker, WT-1, } \\
\text { Desmin (paranuclear point } \\
\text { positive), Vimentin } \\
\text { (paranuclear point positive); } \\
\text { negative: CD99 }\end{array}$ & $\begin{array}{l}\text { Positive expression: CD99, } \\
\text { Vimentin, CyclinD1; } \\
\text { Different degrees of } \\
\text { expression: neuroendocrine } \\
\text { markers; } \\
\text { No expression: epithelial } \\
\text { markers, WT-1, Desmin, S-100, } \\
\text { NF }\end{array}$ & $\begin{array}{l}\text { Positive expression: } \\
\text { neuroendocrine markers } \\
\text { (such as NSE, Syn), NF, GFAP, } \\
\text { S-100 (sertoli cells around the } \\
\text { cancer nest +), epithelial } \\
\text { markers (a few weak } \\
\text { expression of low molecular } \\
\text { keratin); } \\
\text { No expression: Desmin, EMA, } \\
\text { CD99 }\end{array}$ & $\begin{array}{l}\text { Positive expression: epithelial } \\
\text { markers; Partial expression of } \\
\text { neuroendocrine markers; } \\
\text { lack of multidirectional } \\
\text { differentiation; Negative } \\
\text { expression: Desmin et al. }\end{array}$ \\
\hline Molecular pathology & EWS-WT1 gene fusion & EWS-FLI-1 gene fusion & $\begin{array}{l}\text { No specific molecular } \\
\text { changes }\end{array}$ & $\begin{array}{l}\text { No specific molecular } \\
\text { changes }\end{array}$ \\
\hline Clinical features & $\begin{array}{l}>95 \% \text { occurred in pelvic and } \\
\text { abdominal cavity, < } 5 \% \text { in } \\
\text { paranasal sinuses, pleura, } \\
\text { testis, intracranial, liver, lung, } \\
\text { mediastinum, ovary, pancreas, } \\
\text { etc }\end{array}$ & $\begin{array}{l}\text { Usually occurs in lower limbs, } \\
\text { spine, retroperitoneum, } \\
\text { pleura, etc. and can also } \\
\text { occur in nasal cavity and } \\
\text { paranasal sinuses }\end{array}$ & $\begin{array}{l}\text { Prevalent in upper turbinate, } \\
\text { ethmoidal plate, upper third } \\
\text { of nasal cavity (usually in } \\
\text { olfactory cleft) }\end{array}$ & $\begin{array}{l}\text { Can occur in all parts of the } \\
\text { body }\end{array}$ \\
\hline
\end{tabular}


positive, and the molecular pathological changes are EWSFLI1 gene fusion. These features can help differential diagnosis. In this case, WT-1 (+), CD99 (-) can exclude extraosseous Ewing sarcoma and neuroblastoma.

In summary, this reported case of DSRCT emphasizes the importance of incorporating DSRCT in the differential diagnosis of sinonasal tumors. And our study demonstrates the value of imunohistochemical analysis and molecular studies during the diagnosis of tumors which occur in an unusual location.

\section{Abbreviations}

CT: Computed tomography; DSRCT: Desmoplastic small round cell tumor; MRI: Magnetic resonance imaging; PENT: Primitive neurotodermal tumor

\section{Acknowledgments}

Not applicable.

\section{Authors' contributions}

Conception and design, SL; Data collection, TY and SLN; Data analysis and Manuscript preparation, TY, SLN, GL and YT. And all authors read and approved the final version of the manuscript and ensure this is the case.

\section{Funding}

Not applicable.

\section{Availability of data and materials}

All data generated or analyzed during this study are included in this published article.

\section{Ethics approval and consent to participate}

The study was approved by the ethic committee of The Second Hospital of Shandong University and Weifang People's Hospital.

\section{Consent for publication}

Written informed consent was obtained from the patient's son for publication of this case report and any accompanying images. A copy of the written consent is available for review by the Editor of this journal.

\section{Competing interests}

The authors declare that they have no competing interests.

\section{Author details}

'Department of Otolaryngology, The Second Hospital of Shandong University, 247\#, Beiyuan Street, Jinan 250033, China. ${ }^{2}$ Department of Otolaryngology, Weifang People's Hospital, No. 151, Guangwen Street, Kuiwen District, Weifang 261000, China. ${ }^{3}$ Shandong Provincial Key Laboratory of Oral Tissue Regeneration, Department of Bone Metabolism, School of Stomatology, Shandong University, Wenhua West Road 44-1, Jinan 250012, China. ${ }^{4}$ Department of Pathology, Weifang People's Hospital, No. 151, Guangwen Street, Kuiwen District, Weifang 261000, China.

Received: 21 March 2019 Accepted: 22 August 2019

Published online: 31 August 2019

\section{References}

1. Mora J, Modak S, Cheung NK, Meyers P, de Alava E, Kushner B, Magnan H, Tirado OM, Laquaglia M, Ladanyi M, et al. Desmoplastic small round cell tumor 20 years after its discovery. Future Oncol. 2015;11(7):1071-81.

2. Gerald WL, Rosai J. Case 2. Desmoplastic small cell tumor with divergent differentiation. Pediatr Pathol. 1989;9(2):177-83.

3. Ordonez NG, Zirkin R, Bloom RE. Malignant small-cell epithelial tumor of the peritoneum coexpressing mesenchymal-type intermediate filaments. Am J Surg Pathol. 1989;13(5):413-21.

4. Bent MA, Padilla BE, Goldsby RE, DuBois SG. Clinical characteristics and outcomes of pediatric patients with desmoplastic small round cell tumor. Rare Tumors. 2016:8(1):6145.
5. Hayes-Jordan A, LaQuaglia MP, Modak S. Management of desmoplastic small round cell tumor. Semin Pediatr Surg. 2016;25(5):299-304.

6. Zhang WD, Li CX, Liu QY, Hu YY, Cao Y, Huang JH. CT, MRI, and FDG-PET/CT imaging findings of abdominopelvic desmoplastic small round cell tumors: correlation with histopathologic findings. Eur J Radiol. 2011;80(2):269-73.

7. Kis B, O'Regan KN, Agoston A, Javery O, Jagannathan J, Ramaiya NH. Imaging of desmoplastic small round cell tumour in adults. Br J Radiol. 2012;85(1010):187-92.

8. Mainenti PP, Romano L, Contegiacomo A, Romano M, Casella V, Cuccuru A, Insabato L, Salvatore M. Rare diffuse peritoneal malignant neoplasms: CT findings in two cases. Abdom Imaging. 2003;28(6):827-30.

9. Lal DR, Su WT, Wolden SL, Loh KC, Modak S, La Quaglia MP. Results of multimodal treatment for desmoplastic small round cell tumors. J Pediatr Surg. 2005;40(1):251-5

10. Honore C, Amroun K, Vilcot L, Mir O, Domont J, Terrier P, Le Cesne A, Le Pechoux C, Bonvalot S. Abdominal desmoplastic small round cell tumor: multimodal treatment combining chemotherapy, surgery, and radiotherapy is the best option. Ann Surg Oncol. 2015;22(4):1073-9.

11. Kushner BH, LaQuaglia MP, Wollner N, Meyers PA, Lindsley KL, Ghavimi F, Merchant TE, Boulad F, Cheung NK, Bonilla MA, et al. Desmoplastic small round-cell tumor: prolonged progression-free survival with aggressive multimodality therapy. J Clin Oncol. 1996:14(5):1526-31.

12. Mingo L, Seguel F, Rollan V. Intraabdominal desmoplastic small round cell tumour. Pediatr Surg Int. 2005;21(4):279-81.

13. Antonescu CR, W G. Desmoplastic small round cell tumour. In: Fletcher CDM, Bridge JA, Hogendoorn P, Mertens F, editors. WHO classification of tumours of soft tissue and bone. Lyon: IARC Press; 2013. p. 216-8.

14. Briseno-Hernandez AA, Quezada-Lopez DR, Corona-Cobian LE, CastanedaChavez A, Duarte-Ojeda AT, Macias-Amezcua MD. Intra-abdominal desmoplastic small round cell tumour. Cir Cir. 2015;83(3):243-8.

15. Pickhardt PJ, Fisher AJ, Balfe DM, Dehner LP, Huettner PC. Desmoplastic small round cell tumor of the abdomen: radiologic-histopathologic correlation. Radiology. 1999;210(3):633-8.

16. Chouli M, Viala J, Dromain C, Fizazi K, Duvillard P, Vanel D. Intra-abdomina desmoplastic small round cell tumors: CT findings and clinicopathological correlations in 13 cases. Eur J Radiol. 2005;54(3):438-42.

17. Finke NM, Lae ME, Lloyd RV, Gehani SK, Nascimento AG. Sinonasal desmoplastic small round cell tumor: a case report. Am J Surg Pathol. 2002;26(6):799-803.

18. Lopez F, Costales M, Vivanco B, Fresno MF, Suarez C, Llorente JL. Sinonasal desmoplastic small round cell tumor. Auris Nasus Larynx. 2013;40(6):573-6.

19. Trupiano JK, Machen SK, Barr FG, Goldblum JR. Cytokeratin-negative desmoplastic small round cell tumor: a report of two cases emphasizing the utility of reverse transcriptase-polymerase chain reaction. Mod Pathol. 1999;12(9):849-53.

20. Zhang J, Dalton J, Fuller C. Epithelial marker-negative desmoplastic small round cell tumor with atypical morphology: definitive classification by fluorescence in situ hybridization. Arch Pathol Lab Med. 2007;131(4):646-9.

21. Mahooti S, Wakely PE Jr. Cytopathologic features of olfactory neuroblastoma. Cancer. 2006:108(2):86-92.

22. McManus AP, Gusterson BA, Pinkerton CR, Shipley JM. The molecular pathology of small round-cell tumours--relevance to diagnosis, prognosis, and classification. J Pathol. 1996;178(2):116-21.

23. Hill DA, Pfeifer JD, Marley EF, Dehner LP, Humphrey PA, Zhu X, Swanson PE. WT1 staining reliably differentiates desmoplastic small round cell tumor from Ewing sarcoma/primitive neuroectodermal tumor. An immunohistochemical and molecular diagnostic study. Am J Clin Pathol. 2000;114(3):345-53.

\section{Publisher's Note}

Springer Nature remains neutral with regard to jurisdictional claims in published maps and institutional affiliations. 